brazilianpoliticalsciencereview

ART I CLE

\title{
Corruption and Political Participation in the Americas
}

\section{and the Caribbean*}

\author{
Robert Bonifácio \\ Universidade Federal de Minas Gerais, Brazil \\ Rafael Paulino \\ Universidade Federal de Minas Gerais, Brazil
}

\begin{abstract}
This article deals with an issue as yet little explored in the vast literature about political participation: the role of corruption in political engagement. It investigates whether the coexistence, the values and the perception of citizens in relation to corrupt practices and actors have effects on political activism, and it verifies the direction in which this is evolving, whether it is in the direction of engagement in or withdrawal from politics. The unit of analysis is the individual, the geographic sector includes the Americas and the Caribbean, and the time frame includes biennial intervals between 2004 and 2012. A theoretical discussion and empirical analysis of the data from the Americas Barometer is used. Five distinct types of political participation were identified: contact with political and governmental actors, community activism, partisan and electoral activism, voter turnout and protest activism. The article concludes that the experience with corruption and the tolerance for bribe increase the chances of engagement in participative activities, going against the principal contributions of the specialized literature.
\end{abstract}

Keywords: Corruption; political participation; political behavior; Americas and the Caribbean; Americas Barometer. 


\section{bpsr}

Nom orris (2011) emphasizes that democracy, understood both as an ideal to be followed (normative dimension) as well as a type of political system (analytical dimension), currently finds itself disseminated around the world. Analyzing the adoption of political systems in the past century, Moisés (1992) maintains that democracy was the main character, agreeing with the term used by Pasquino (1990) to characterize the political life of the period: "celebration of democracy". Huntington (1994) emphasizes that, from the mid-19th until the end of the $20^{\text {th }}$ centuries, changes occurred in non-democratic systems into democratic systems, a movement that he titled "waves of democratization". Bonifácio (2014), in turn, observes moderate but sustained growth in the democratic character of political systems (free countries) over time, in all parts of the world, considering the period from the 1970 s to the present ${ }^{1}$.

As for the characteristics of a democratic system, we understand that political participation may be characterized as the most voluntary and activist dimension. First, because it is grounded in autonomous mobilization, free of legal obligations $^{2}$. Second, related activities are not necessarily restricted to a unique environment, which means that they are practiced by various social actors in various arenas.

Perhaps because of these characteristics, the number of studies on political participation is large. What we attempt in this study, however, is to investigate an issue as yet little explored in the specialized literature: the role of corruption in the shaping of political engagement. Could the coexistence, the values and the perception of citizens in relation to corrupt practices and actors have effects on political activism? If so, in what direction is it evolving: in the direction of engagement in or withdrawal from politics?

To meet our objectives, we examined studies whose themes approached the research problem selected and conducted empirical analyses. As for the final aspect, we used data, relevant to American and Caribbean citizens in dozens of

\footnotetext{
1 The author uses data available from Freedom House. Available at: http://www.freedomhouse.org/about-us. Accessed on 06/05/2013.

2 The exception is for the vote, which is compulsory in some countries.
} 
countries, from the Americas Barometer ${ }^{3}$ (henceforth, AB). Data relative to the elections in 2004, 2006-7, 2008, 2010 and 2012 were accessed. Due to the size of public and the time period that the set of studies covers, it is possible to identify trends about the possible relationship between corruption and political participation.

The present study is organized as follows: in the next section, we define political participation, select its indicators and analyze its dimensionality. Next, we discuss the effects of corruption in individual political orientations and describe their indicators. The third part is dedicated to the methodological aspects of the study and is followed by the data analysis. We conclude with the final considerations.

\section{Political participation: definition, indicators and dimensionality}

The debate about political participation is extensive. There are, for example, several views about the environment in which the phenomenon and its dimensionality, beyond the repertoire of participatory activities, develop. In Brady (1999), Borba (2012) and Bonifácio (2014), some of the principal studies that deal with these issues are approached and the last author emphasizes that the unique consensual point among them is the consideration that participation is a behavior, an action, and not an attitude, which is something imbued with subjective character.

We consider political participation to refer to activities exercised by citizens, in several areas, with the objective of influencing the dynamics of power. Therefore, we understand that participating means taking part in something (FIALHO, 2008), that the phenomenon is expressed by activities and that it may develop in various arenas seeking, in either a conflictive or cooperative way, to influence the distribution of power (REIS, 2000).

From this definition, it is possible to select empirical indicators (Chart 01). Two considerations, however, are shown to be essential. The first refers to the extent of the participatory dynamic. We do not incorporate the conception that its results can contribute to a structural change in the State (PIZZORNO, 1975)

\footnotetext{
3 We thank the Latin American Public Opinion Project (LAPOP) and its major supporters (the United States Agency for International Development, the Inter-American Development Bank, and Vanderbilt University) for making the data available.
} 
because the occurrence of revolutionary movements is seen infrequently throughout history and what we seek to study are the most common movements. Second, we include among the indicators only activities of an unequivocal political nature. Thus, we leave aside certain groups and associations usually linked to political participation, such as women's and religious groups, for example. The manner in which the $\mathrm{AB}$ questionnaire treats the relationship of these organizations does not permit the interpretation that engagement is necessarily linked to political issues.

Chart 01. Indicators of political participation

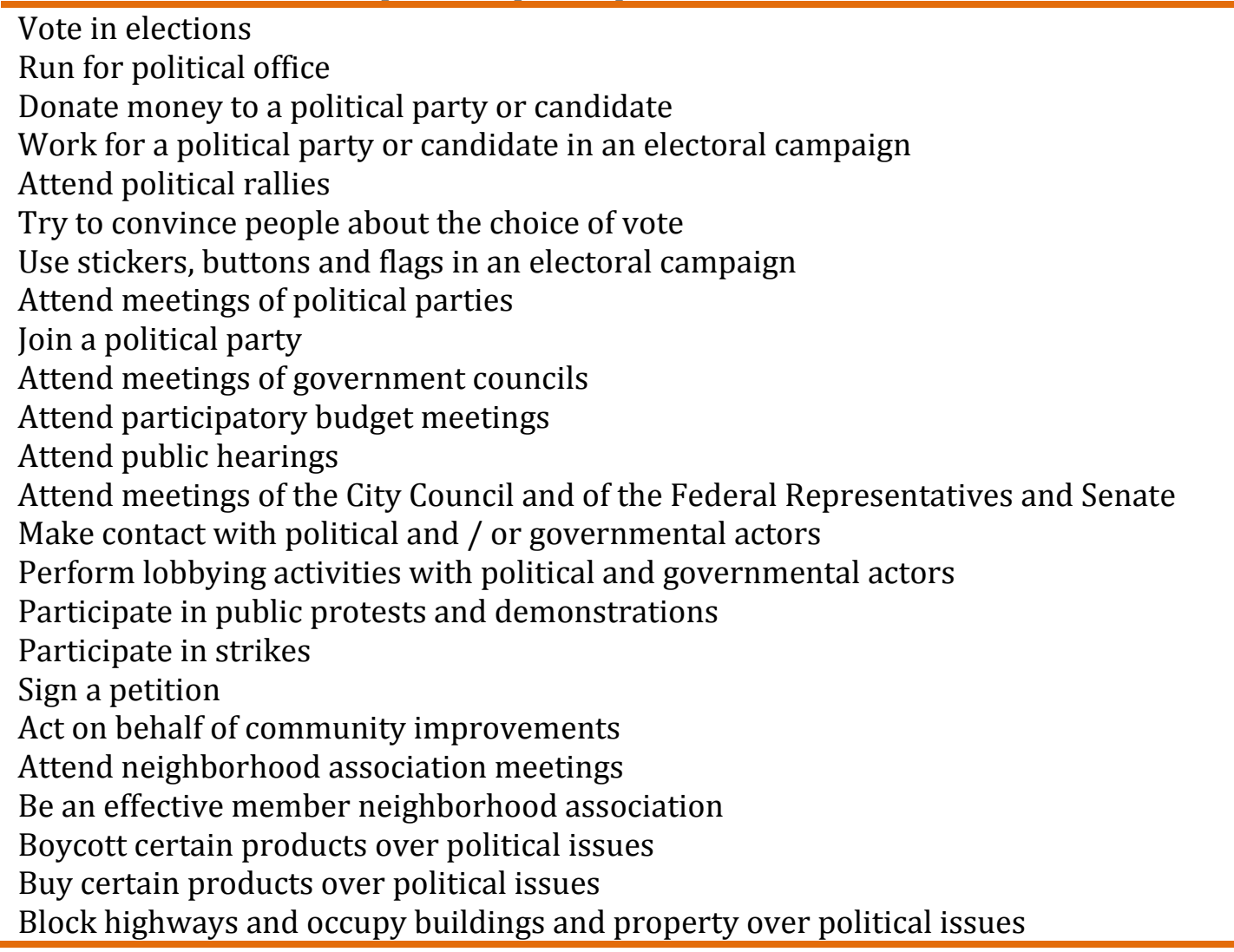

Not all these indicators are present in the $\mathrm{AB}$ database, and it is possible to work only with thirteen of the indicators, listed as follows (more information in Appendix A, on BPSR Database):

01 . Voting in presidential elections;

02. Working in electoral campaigns;

03. Contacting representatives (state and federal);

04. Contacting governmental political actors (ministers and secretaries);

05. Contacting local political actors (mayors and military authorities); 
06. Contacting council members and local governmental actors;

07. Acting to solve problems in the communities in which they live;

08. Attending community association meetings;

09. Attending political party meetings;

10. Attending public hearings at local councils or city halls;

11. Trying to convince others about the choice to vote;

12. Participating in demonstrations or public protests;

13. Signing petitions.

From the selection of political participation indicators, we investigate the nature of the dimensionality of the phenomenon: do they express a unique dimension, or can they be grouped into different dimensions, constituting specific modalities?

Performing the exploratory factor analysis (Table 01), we distinguish prima facie three modes of political participation: contact with political and governmental actors, community activism and electoral and partisan activism. The first mode expresses direct contact between representative and represented, without the presence of demonstrations or related activities that aim to exert public pressure. However, in the way that these issues are placed in the questionnaire, it is not possible to discern whether the contact occurs in an individual or collective manner, nor the nature of the issues involved. Community activism, in turn, denotes action on small-scale political issues of local scope. It aims to influence policies and actors that handle the specific problems of a particular community. Electoral and partisan activism includes activities that aim to influence electoral results, notably the national discussions, activities and organizations included within this mode.

More detailed analyses of the data indicate the existence of two more modes of political participation: voter turnout and protest activism. The greater value of the coefficient of the variable related to voting has a low level, not surpassing the 0.450 ceiling. This result indicates that the variable is not linked to any specific group, that it constitutes a specific segment. Furthermore, this interpretation converges with the contributions of Verba, Nie and Kim (1987), Norris (2002), and Booth and Seligson (2009), who claim the existence of a specific 
mode of political participation, voter turnout. The statistical coefficient of the variable related to protest shows a similar characteristic in the first four rounds. However, in 2012, with the inclusion of the variable related to signing petitions and the questions in the questionnaire, both variables show expressive values (greater than 0.7) in a unique factor, thus constituting what we call protest activism.

Table 01. Exploratory factorial analysis with indicator variables for political participation



Source: Americas Barometer, Latin American Public Opinion Project (LAPOP), www.LapopSurveys.org.

These results further strengthen the findings of the studies such as those by Verba, Nie and Kim (1987), Norris (2002), Booth and Seligson (2009) and Teorell, Torcal and Montero (2007), that assert the multidimensional nature of political participation. Faced with so much evidence related to the various modes 
of political participation, we consider it inappropriate to conceptualize it as a single phenomenon, restricted to the governmental and electoral environment, as Milbrath (1965) understood. Instead, our empirical assessment allows us to advance five types of political participation, as shown in Chart 02.

Chart 02. Types of political participation

01. Contact with political and governmental actors: contact with state and federal representative, with local political actor, with governmental actor and with councilman and local governmental actors.

02. Community Activism: attend meetings of the neighborhood association, act on behalf of improvements in the community and attend hearings of the City Council and City Hall.

03. Electoral and Partisan Activism: work on an electoral campaign, attend meetings of a political party, try to convince others about the choice of vote.

04. Voter turnout: having voted in the previous election.

05. Protest activism: participation in demonstrations and protests and signing petitions.

\section{Corruption and political behavior}

Corruption has long occupied a good part of the attention of scientists in several areas. Lipset and Lenz (2002) assert that the explanation for such interest lies in its ubiquity in complex societies. Perhaps it is due to this characteristic that Euben (1989) understood that the conceptual history of corruption is uncertain. According to the author, the term was used in two distinct contexts: to refer to a specific human activity - as, for example, bribery - or in a more general sense of destruction, devastation or adulteration of an organic material. It may be considered, therefore, that the word has negative connotations and is assimilated into notions of decay, disintegration and degeneration.

Filgueiras (2008) claims it is a mistake to write about a political theory of corruption as there is no consensus regarding its meaning in the tradition of Western political thought. The most appropriate would be, therefore, to speak about approaches to corruption. From studies such as that of Heidenheimer, Johnston and Levine (1989), it is possible to conceptualize three main approaches to corruption: (01) one that considers it an infractional act, which opposes or transcends laws and official norms (MANZETTI and WILSON, 2009; NYE, 1967); (02) another, which conceptualizes it as a calculated behavior that benefits the corruptor, given the specific opportunities of the context of which the action is part (ROSE-ACKERMAN, 1999) and, finally, (03) there is a perspective that treats corruption as intimately linked to the normative system in effect in every society (CALERA, 1997; FILGUEIRAS, 2008; SEÑA, 1989; VALDÉS, 1995). 
The indicators of corruption that we use will follow, in part, these three prevailing views of the phenomenon. We seek to verify the proximity of the citizen with the phenomenon that can vary from his (01) experience with situations of requests for bribes (what we call experience with corruption) to (02) tolerance for bribes (tolerance for corruption), and (03) perception of corruption among public officials (perception of corruption). So, we have a measure of coexistence with corrupt acts, a value related to a specific act of corruption and a general perception of the incidence of corruption within a specific group, respectively ${ }^{4}$. We do not use macro-level measures of corruption.

Table 02. Frequency of corruption indicators

\begin{tabular}{lccccc} 
& 2004 & $2006-7$ & 2008 & 2010 & 2012 \\
\cline { 2 - 6 } Experience & $11.9 \%$ & $11.8 \%$ & $11.1 \%$ & $11.2 \%$ & $11.4 \%$ \\
Tolerance & - & $24.6 \%$ & $21 \%$ & $15.6 \%$ & $15.7 \%$ \\
Perception & $77.0 \%$ & $80.0 \%$ & $80.0 \%$ & $80.0 \%$ & $78.7 \%$ \\
\hline
\end{tabular}

Source: Americas Barometer, Latin American Public Opinion Project (LAPOP), www.LapopSurveys.org.

Regarding the frequency of these indicators (Table 02), we note that the percentages of the aggregate experience with situations of requests for bribes among public officials and police are very close in each one of the five rounds of the $\mathrm{AB}$ : about $11 \%$. Stability in the percentages is also present in the perception of corruption. In all rounds, about $80 \%$ of the citizens think that corruption is common or very common among public officials. The percentages of tolerance for bribes are distributed in a somewhat distinct way, gradually decreasing during the period analyzed. Despite the lack of data for the 2004 round, we identify a drop of approximately $04 \%$ from the $2006-7$ round to the 2008 round, and of $06 \%$ from this round to the 2010 round, stabilizing from this year to 2012.

From these results, we consider that Americans and Caribbeans hold a strongly negative view of the integrity of the actions of public officials, since 08 out of every 10 perceive the incidence of corrupt behavior among this group of workers. Furthermore, there seems to be a strong value - increasingly stronger

\footnotetext{
4 The indicator variables for experience with requests for bribe, intolerance for bribe and perception of corruption among public officials are encoded in the $\mathrm{AB}$ survey in the following manner, respectively: EXC2 and EXC6, EXC18 and EXC7. For more detail, we suggest consulting the questionnaire applied in Brazil in the 2012 round. Access: http://www.vanderbilt.edu/lapop/brazil/ABBra12-v10.0.2.6-Por-120722_W.pdf. Accessed on: 07/31/2014.
} 
over the years - against the acceptance of payment of bribes for things to happen or to work. There is, however, the risk that this type of response is conditioned by a socially desirable behavior. The scenario of the experience with corruption, in turn, is very distinct. Only 01 out of every 10, approximately, report having experienced situations of requests for bribes in their contacts with public officials and police.

The differences in percentages make sense, since the first two measures have a subjective character and the last one is more objective, indicating the fact of an actual occurrence. Due to the difference in the nature of the variables and the percentage differences, we believe that the magnitude of their effects on participative engagement can be distinguished.

\section{The role of corruption in political behavior}

The contradictory views about the role of corruption in the political sphere are also present in the specialized literature. For around at least seven decades, scientists have argued both its possible negative as well as its positive effects.

When the debated issue is the consequences of corruption for the political system, Seligson (2002) identifies, among those scientists classified by him as "functionalists", the view that corruption would have a positive role for countries with authoritarian political regimes, since it would serve as an instrument to untie the knots of the state bureaucracy. It would be a kind of lubricant that makes the machines function. Huntington (1968), for example, suggests that corruption may be a way of overcoming the traditional norms and the bureaucratic regulations that hamper economic development. Moreover, it would enable a more consistent tie between the citizenry and the governments. It would contribute, therefore, to the stability of the political system.

Nevertheless, after the continuous process of democratization of countries, especially after the "third wave of democratization" (HUNTINGTON, 1994), the considerations of the role of corruption in the system and in the political behavior begin to change connotation. It became common to consider it as a phenomenon whose consequences are negative for the stability and quality of the political system. Authors like Doig and McIvor (1999) and Doig and Theobald 
(2000), for example, suggest that the high rate of perception of corruption is related to the low level of institutional trust. This favors the possibility of damage to the stability of the political system. Seligson (2002), in turn, identifies, among those "victimized by corruption", the lowest levels of support for the democratic political regime as well as the lowest levels of interpersonal trust, having nonvictimized citizens as the comparison. Della Porta (2000) provides empirical evidence that relates corruption to the perception of deficient performance of governments.

Focusing on the field of study about political behavior, we consider that relatively recent studies are fairly consensual in indicating the adverse effects of corruption on the attitudes and behaviors understood as civic.

From Warren's (2012) perspective, corruption undermines the inclusive nature of political processes, such as the relationship between representatives and represented, because it compromises the power of the vote and the voice of citizens who aim to influence collective decisions, removing the power and the resources from the public arena to partial relationships, individual and private. As a consequence, it weakens democratic legitimacy due to the exclusion of citizens from the decisions which affect them. Moreover, corruption affects democratic culture, the author emphasizes. If corruption spreads, the citizens gradually lose faith in the process of public decision making - seeing it as not publicly available and justifiable - and, in consequence, it is likely that they will become increasingly cynical regarding public discourse and deliberation. From these considerations, Warren (2012) suggests that corruption enables the reduction of the horizon of collective actions, shrinking the sphere of democracy in this field.

Warren's (2012) and Hirschman's (1983) ideas are close. This author looks to socio psychological aspects for the explanation for the cyclical involvement of the individual in activities related to the public (individual identified as "citizen") and private (individual identified as "consumer") spheres. Corruption is important for understanding the disengagement of the "citizen" in activities from the public sphere, activities that are related to political activism in its varied forms. Acceptance and immersion in corrupt acts may be understood as reactions to a change of preference: the loss of satisfaction through the action of public interest becomes compensated by material gains arising from corruption. 
Persistent immersion in corrupt acts leads individuals to think that public activities are vile by nature and, thus, what was initially a reaction of discontent with the public sphere becomes a determinant of additional and profound discontent that, in turn, prepares the setting for more corruption. At the end of the process, the public spirit is completely eliminated. Under these conditions, corruption may provide the "citizen" with a rapid transition back to its role as "consumer".

Hirschman's (1983) study is perhaps the only one that relates, even though in a strictly theoretical way, corruption with political participation. We do not find studies in the specialized literature that have this theme in sight. We do identify, however, studies that associate the experience and perception of corruption with political attitudes. The results of these studies help us to hypothesize the relationships in a study and develop the empirical analysis.

In Seligson's (2001, 2002) studies, the objectives are similar: to analyze whether the experience with corruption is associated with diffuse support for the democratic political regime. For the author, there are two main motives for studying such a relationship. First, the high incidence of corruption in Latin American: several countries in the region show the highest rates in the index of perception of corruption of the International Transparency, and the data of the International Crime Victim Survey indicate that a Latin American citizen has about fifteen times greater chance of experiencing corruption than a citizen from Western Europe. Second, the author cites the extensive history of political instability in the region.

In Seligson's first study, the investigation is limited to Nicaragua and used data from two opinion surveys, carried out in 1996 and 1998, the latter performed after a national campaign in favor of a more efficient public administration. The author performed various statistical tests and, in all of them, he found association between higher levels of experience with corruption and lower levels of support for the democratic regime. In the 2002 study, Seligon expanded the analyzed cases - El Salvador, Nicaragua, Bolivia and Paraguay - and used another data source, the $A B$, from 2004. The results are the same: the greater the experience with corruption, the lower the democratic legitimacy. This study also focuses on interpersonal trust, understood as a facilitator for forming the deep and lasting 
civil associations that are vital to the constitution of trust in the political system as a whole. Also, in this issue, corruption presents adverse effects; that is, the author verifies association between higher levels of experiences with corruption and lower rates of interpersonal trust.

Seligson's $(2001,2002)$ studies show that the greater the experience with situations of requests for bribes, the more negative is the view of the citizens with respect to the democratic institutions and processes and the levels of trust are also lower. That is, experience with corruption contributes to the low attachment to the democratic political regime and to the lower predisposition to associativism.

In Zéphyr (2008) and Salinas and Booth (2011), the objective is also in the relationship between experience with corruption and democratic legitimacy, but the analysis is broader as it includes citizens from a larger number of countries. The authors use data from the 2006-07 and 2008 rounds, respectively, of the AB. Zéphyr (2008) uses two measures of democratic legitimacy and, in both cases, the results show that higher levels of experience with corruption are linked to lower levels of democratic legitimacy. Salinas and Booth (2001) use a wide range of explanatory variables, among them, the experience with situations of requests for bribe, and the perception of corrupt behavior among public servants to explain particular democratic attitudes, namely (01) expressed preference for democracy, (02) the support for basic democratic participation rights, and (03) the tolerance toward contestatory forms of political participation. The authors identify distinct relationships between the two variables for corruption with all three variables being explained: experience with corruption shows, in all cases, a negative association with democratic attitudes; on the other hand, the perception of corruption shows a positive association with democratic attitudes.

Bohn (2012) understands that, different from autocratic systems, the legitimacy of democratic systems derives from the mass support for its principal processes such as free and fair elections, institutionalized freedoms and rights, as well as transparency and accountability in public institutions. The presence of corruption in the democratic environment vitiates the interactions between the citizen and the State, and potentiates the reduction of trust and satisfaction of individuals with the system and its primary institutions, that author suggests. Bohn (2012) directs his investigation from these considerations, analyzing the role 
of the perception and the experience with corruption in the satisfaction of the citizens with actually-existing democracy, using data from the $2010 \mathrm{AB}$. The association between the two variables for corruption with satisfaction with actually-existing democracy are similar in that they are both negative. That is, the higher the levels of experience with and perception of corruption, the lower the satisfaction with democracy. However, in the relationship between experience with corruption and satisfaction with democracy, the intensity of the association reaches a low level and there is no statistical significance.

Although aiming at explaining different types of political orientations, all studies examined show the same finding: the proximity to corruption - whether due to experience with corrupt acts or due to the perception of its existence at a high level -undermines the democratic disposition of the citizens. Thus, we hypothesize that having experience with situations of requests for bribes, being tolerant for bribes ${ }^{5}$ and having a high perception of corruption among public officials, increases the chances of non-engagement in all participative activities.

Although it is important to consider the existence of various and contradictory motivations for the adherence to each one of the modalities ${ }^{6}$, we do not discriminate different hypotheses for each of them because we see no differences in the process of political engagement, given that it is always voluntary and activist. Moreover, the studies that we approach in this topic indicate clearly an adverse effect of corruption on different types of political attitudes (adherence to democracy, tolerance for competing forms of participation, political trust etc.). These two questions serve us as references for constructing a single, general hypothesis about the relationship between corruption and political participation.

\section{Methodological strategies}

As noted above, the empirical analysis rests exclusively on treatment of the data extracted from the $A B$, a set of opinion surveys applied among citizens from several countries in the Americas and the Caribbean, conducted by the Latin American Public Opinion Project (LAPOP), of Vanderbilt University, coordinated by

\footnotetext{
${ }^{5}$ We do not talk about the effects of tolerance for bribes on political behavior, because we found no investigations with this theme in the specialized literature. Thus, we generated hypotheses on this issue, following the trend found in the literature for the two other indicators of corruption used. ${ }^{6}$ It is worth emphasizing that our study makes reference to the purpose of political participation and not to the individual motivations that justify the event.
} 
Professor Mitchell Seligson. This choice is based on several criteria. One of them is the richness of the questionnaire. The $\mathrm{AB}$ contains dozens questions about political participation and also addresses the citizen's proximity with corruption. In addition, it covers an uninterrupted time period of about a decade, with the application of biennial surveys. Finally, the samples of surveys conducted in each country are calculated in such a way as to permit the generated data to be representative of the full population.

The sample size varies from country to country. For this reason, we always consider all the statistical tests performed with the variable weight1500, a procedure that guarantees that the sample of all of the countries contains the same number of cases, 1500.

In the first topic of this study, we conducted an exploratory factor analysis with the polychoric correlation matrix, the most appropriate when the variables used are binary and categorical. The results of this test permitted the creation of political participation indices, one for each modality identified. The value of "zero" in the indices indicates no participation, and values greater than or equal to "one" indicate participation, but we aggregate all these last values into just one category. We chose this procedure because we observed that the values, separately (categorical and not binary), have always appeared greatly inferior to the totality of non-participation cases, requiring an aggregation which, if not done, could compromise the quality of the results of the statistical tests. From this procedure, we get a more balanced distribution of frequencies possible between participation and non-participation.

Due to the choice about the structure of the political participation indices, we ruled out the use of two types of regression: linear and multinomial logistic. The first has, as a pre-requisite, the continuous nature of the response variable, and the second requires more than two categories in the response variable. The binary logistic regression test, which requires the binary response variable, appeared to be the more appropriate for the data that we have.

Regarding the variables for corruption, it is important to emphasize that the data from the $\mathrm{AB}$ have some technical limitation in the measurements. The most important of these is related to the experience with corruption. We note, in the data from the 2012 round, the lack of questions about requests for bribes in 
some situations for the citizens of Canada7. Moreover, in the same round, the filter question is not applied to each one of the situations of requests for bribes in a considerable number of countries. For example, before being asked if the interviewee had to pay a bribe in order to have his petition recognized in the municipality, he is asked if he sent any petition to the municipality during the last year. The application of these filter questions is not uniform for the citizens of all countries in which the survey is conducted. In some cases, they were even included in the questionnaires. For the other rounds, the problems persist and are amplified: despite the existence of the filter questions in the questionnaires, they are not included in the database. Moreover, there are high percentages of nonresponses (missing values) in the response categories for the variables about experience with situations of requests for bribe in all five rounds ${ }^{8}$.

Due to these limitations, we use only two variables about experience with corrupt acts: experience with the situation of requiring bribes by some police and official public. None of the limitations identified above are present in these variables. There are also limitations in the case of the variables for intolerance and the perception of corruption, although they are of lesser magnitude. In both, there is a lack of application of the question in particular countries and in some rounds 9 .

\footnotetext{
${ }^{7}$ In the municipality (variable "exc11"), in the workplace ("exc13"), with a judge ("exc14"), in the public medical services ("exc15") and in the school in which the child studies ("exc16").

8 To exemplify the problems highlighted, we cite the 2012 round which has a total of 39000 cases (using the weight "weight1500" which allocates 1500 cases for each country). In this round, the percentages of missing values for the filter question and for the variable that asks about the payment of bribe for each one of the following situations are, respectively: the municipality (exc11): $36.8 \%$ and 22\%; workplace (exc13): $36.7 \%$ and $48.1 \%$; judge (exc14): 36.7\% and 36.7\%; medical services (exc15): $36.8 \%$ and 46.9\%; school (exc16): 36.7\% and 39\%. The percentages are high, which interferes with the data analysis and are also non-corresponding, which is an error, since only those who answered "yes" or "no" to the question of experience with corruption passed through the filter question. Thus, the percentage of missing values for both variables should be identical. More aspects may be debated about the quality of the measurements, but that is not the focus of the present study. For more information on this, consult the following studies: Abramo (2004, 2005a, 2005b), Seligson (2001, 2002), Zéphyr (2008) and Bonifácio (2014).

${ }^{9}$ For tolerance, in the 2004 round, the variable is applied only in Mexico and in Ecuador. In the 2006-07, 2008, 2010 and 2012 rounds, the variable is not applied to the following blocks of countries, respectively: USA, Bolivia, Canada and Colombia/Canada and USA/Canada. In the case of the perception of corruption, the question is not applied in Paraguay in the 2006-07 round.
} 
In the regressions ${ }^{10}$ (table 3 ), the response variables follow the findings coming from the factor analysis, described in Table 01 and Chart 02 . The only difference is the segmentation of the voter turnout in two variables, the indicators of compulsory voting and optional voting. Within the scope of the explanatory variables, we use the three variables for corruption, but also variables of interactions with these variables among themselves and among each one of them with the continuous variable for schooling. We also include indicators of socioeconomic and demographic conditions in the regression models as control variables. Moreover, we use the fixed effects ${ }^{11}$ for the indicator variables for countries - not shown in the tables below, due to the space limitation - and the variable placed as reference, for each round and each mode of participation, is that which shows the greatest percentages of frequency in the corresponding index ${ }^{12}$.

The regression tests were performed using progressive incorporation models. Models 01, 02 and 03 each encompass only one indicator variable for corruption: perception, tolerance and experience, respectively. Due to space limitation, the pertinent results of each one of these models are listed in only one column, for each round. Model 04, in turn, comprises all the indicator variables for corruption; and, Model 05 is the most complete, containing all the variables of the previous model plus those relative to socioeconomic conditions and the variables of interaction ${ }^{13}$. In all five models (table 3 ), the variables for the countries are

10 To interpret the regression coefficients in the text, we adopted the "percentage effect" measure rather than odds ratio, as we consider it easier to understand. To transform the odds ratio into percentage effect values, we used the following formula: $[\operatorname{Exp}(B)-1]{ }^{*} 100$.

11 We did not perform multilevel or hierarchical regression because the values of the intraclass correlation coefficient (ICC) - a measure of confidence resulting from the ratio of the variance between the units of analysis and the total variance - for models that contain only countries, considering all types of political participation, did not attain a value greater than or equal to 0.10 . In this case, the use of the multilevel or hierarchical regression may be dispensable (LEE, 1999).

12 The reference variables are described below, considering each modality of participation and each round (2006-07): "contact" = Costa Rica, "community ativ." = Dominican Rep., "electoral ativ." = Dominican Rep., "Comp. voting = Peru, "Opt. voting = Guyana and "protest ativ." = Peru; (2008): "contact" = El Salvador, "community ativ." = Paraguay, "electoral ativ." = Honduras, "Comp. voting = Ecuador, "Vol. voting = Venezuela and "protest ativ." = Peru; (2010): "contact" = El Salvador, "community ativ." = Haiti, "electoral ativ." = Haiti, "Comp. voting = Uruguay, "Vol. voting = El Salvador and "protest ativ." = Haiti; (2012): "contact" = Jamaica, "community ativ." = Haiti, "electoral ativ." = Guyana, "Comp. voting = Peru, "Vol. voting = Belize and "protest ativ." = Haiti. Some variables are omitted from the tests, due to lack of data in some rounds. Contact the authors via e-mail for detailed information.

13 For 2012, the family income categories are different from the other years. The values are: from 0 to 05 fractions (reference), from 06 to 10 fractions and from 11 to 16 fractions. 
present. It is worth noting that the data from 2004 are not used in the regressions due to the absence of the indicator variable for tolerance for corruption in that round.

In addition to analyzing the relationships between the explanatory variables with the response variable, we also analyzed the adjustment of the models (predictive capacity). Several coefficients may be useful in this way, as, for example, those obtained from the Chi-square test, the Wald test, the Chi-square test of likelihood ratio, the Hosmer-Lemeshow test and the Pseudo R-squared of Cox and Snell, Nagelkerke, Effron and McFadden (adjusted or not adjusted). Even without consensus among specialists, it is common to use the coefficients of the Chi-square ${ }^{14}$, Chi-square of likelihood ratio ${ }^{15}$ and MacFadden's Pseudo R-squared ${ }^{16}$ tests. Therefore, we included them in the models.

Our analyses of the degree of adjustment of the model, following the assumptions of the test, only took into account comparisons between nested models, in this case Models 04 and 05. We observe that the values of the Chisquare and of the Chi-square with likelihood ratio of the more complete models always surpass the critical value, when compared with the values relative to the four models. These results enable us to claim that the progressive addition of variables to the models contributed to the predictive capacity thereof.

14 To analyze the predictive capacity using this test, the category (ies) included in a more complete model should be multiplied by 3.84, generating a critical value of Chi-square. Then, subtract the Chi-square value of the more restricted model from the Chi-square value of the more complete model. If the value resulting from the subtraction is greater than that of the critical Chi-square, one can consider that the model with more variables has greater explanatory capacity than the model with fewer variables.

15 The ratio of likelihood test compares the adjustment of two models, which should be nested (one of the models is derived from the other). Its calculation is done by computing the adjustment of the less restricted model minus the adjustment of the unrestricted model (using $0-2 * \log$. of the likelihood). The Chi-square test is applied to the ratio found in the previous calculation, taking into consideration the difference between the degrees of freedom (number of independent variables in the unrestricted model minus the number of independent variables in the restricted model). If the Chi-square test is statistically significant, one may consider that the model with more variables (unrestricted) has greater explanatory capacity than the model with fewer variables (restricted), given a specific level of significance.

${ }_{16}$ MacFadden's R-squared indicates to what extent the inclusion of the independent variables in the model contributes to reducing the variance of the result, ranging between 0 and 01 . Zero ( 0 ) signifies that the set of independent variables does not contribute to the prediction of the dependent variable; one (01) signifies that the set of variables fully explains the dependent variable (LONG and FREESE, 2006). 
The tests of predicted values contributed to the deepening of the analyses of the relationship between corruption and political participation. The tests performed help to better understanding the relationship of the interactions between the variables for corruption (represented by straight lines) and the propensity for participation (yaxis). In all cases, we also used the continuous variable for schooling (x-axis) ${ }^{17}$.

For the tests of logistic regression and predicted values, only part of the data are found in the article, in order to avoid an excessive number of pages. In both cases, only the data from 2012 are presented, for the community activism modality (Table 03 and Graph 02), in addition to the predicted values in relation to general participation (Graph 01). However, we report below the results considering data from all rounds.

\section{The role of corruption in political participation among Americans and Caribbeans: data analysis}

Citizens who have experience with corruption are more likely to engage in participative activities than those who do not have this type of experience. The magnitude of the association between this variable and the variables relative to political participation always appears greater among all the indicators of corruption, and also always checks for statistical significance. Consistency in the direction of the associations of the five models is also notable, considering all modalities of participation and all rounds, even when variables of socioeconomic conditions are inserted into the models. Additionally, we can consider that the results support the interpretation that the negative relationship between corruption and political participation is not confirmed. That is, contrary to what found by the literature thus far, experience with corruption appears to increase the likelihood of political engagement of Americans and Caribbeans.

Such results are valid for nearly all modalities of participation, except those relative to voter turnout. In the case of compulsory voting, there is an inverse direction in the sense of association, predominantly the negative effects for participation. In the case of optional voting, the direction of association is variable, predominantly in the positive sense, except for the complete models from the 2006-07 and 2008 rounds. In both of those cases, statistical significance occurs in the smaller part of the associations.

\footnotetext{
17 The choice of schooling is based on the identification, from the data and specialized literature, that this socioeconomic characteristic is what most discriminates activism and political passivity, nearly always indicating that the higher the level of schooling, the greater the chances of political engagement.
} 
The results for the effects of tolerance for corruption on political participation are similar to those described above. In cases of contact with political and governmental actors, of community activism, of electoral and partisan activism and of protest activism, we observed that those tolerant of bribes are more likely to engage in these participative activities than those intolerant of it. The main difference between these results and those found in the relationship between experience and participation falls in the intensity of the associations. There are always smaller modular values, and also the statistical significance is not always present in all the models created. Once again, therefore, the proposition advancing a negative association is not confirmed since tolerance for corruption increases the likelihood of political engagement of Americans and Caribbeans.

In the two cases of the voter turnout modality, considering compulsory voting and optional voting, the effects of this tolerance are variable. In the first case, the negative direction of association predominates in the complete model for the first two rounds, and in the negative direction for all models in the last two rounds. In the second case, we observed the negative direction of association in all models from the 2006-07 and 2008 rounds, and in the positive direction for the more complete models of the 2010 and 2012 rounds.

Regarding the effects of the perception of corruption, we observed a prevailing negative direction of association in cases of contact with political and governmental actors and of electoral and partisan activism. That is, those having a high or moderate perception of corruption among public officials are less likely to engage in these modalities of political participation than those having no or little perception thereof. In relation to community activism, protest activism and voter turnout (compulsory voting), the direction of the associations is variable, predominantly in the positive direction, sometimes in the negative direction, considering all models and rounds. Differing from most of the results, voter turnout (optional voting) prevails in the positive direction, but with no statistical significance for several models, mainly in the complete models. This panorama makes it difficult to identify any trend of association between the perception of corruption and political activism in these cases. Therefore, we do not suggest any response, neither corroborating nor refuting, to the propositions under scrutiny. 
In relation to the variables of interaction (profiles which aggregate variables about corruption and also the variable for schooling), it is not possible to identify any trend in their association with any of the modalities of political participation. The direction of the association and of the modular values of the effects varies greatly, in addition to there being few statistically significant cases.

Due to this difficulty with interpreting the data via logistic regression, we performed tests of predicted values that relate profiles constructed from the variables about corruption (identified by straight lines) to the propensity for engagement in participative activities (y-axis) and levels of schooling (x-axis) ${ }^{18}$. In Graph 01, we constructed combinations of variables about corruption and we used an index which aggregates all the participative activities. In the other graphs, referring to each one of the modalities of political participation (only Graph 02, regarding community activism, is resent in the text), there is the illustration of the propensity for political engagement among those close to and those not close to corruption, in the three measures (experience, tolerance and perception).

In a general way, we identify three main trends in the results: (01) independently of the characteristics of the profile, with greater propensity for participation, in most of the cases ${ }^{19}$ there is a presence of experience with corruption; and (02) in none of the cases is the profile that indicates absence of proximity with corruption the one with the greater propensity for participation. On the contrary, it always figures in intermediate or final positions. Finally, we can emphasize that, in all profiles, (03) there is an increased propensity for participation as the level of schooling increases. That is, independent of the proximity of the citizen to corruption, schooling always raises the propensity to participate.

It should be pointed out that, in every modality of political participation (except those relative to voter turnout), the differences in the propensity to participate are greater among those with and those without experience with corruption, compared with the opposing profiles of other indicators of corruption. From these observations, we consider that experience with corruption is the indicator that best discriminates participative behavior among Americans and Caribbeans.

${ }^{18}$ Only the data referring to the 2012 round are reported in the present study, due to space limitations. However, the syntaxes may be accessed in the database section of the BPSR's website. ${ }^{19}$ Except for voter turnout, considering compulsory voting and electoral and partisan activism in the 2012 round. 


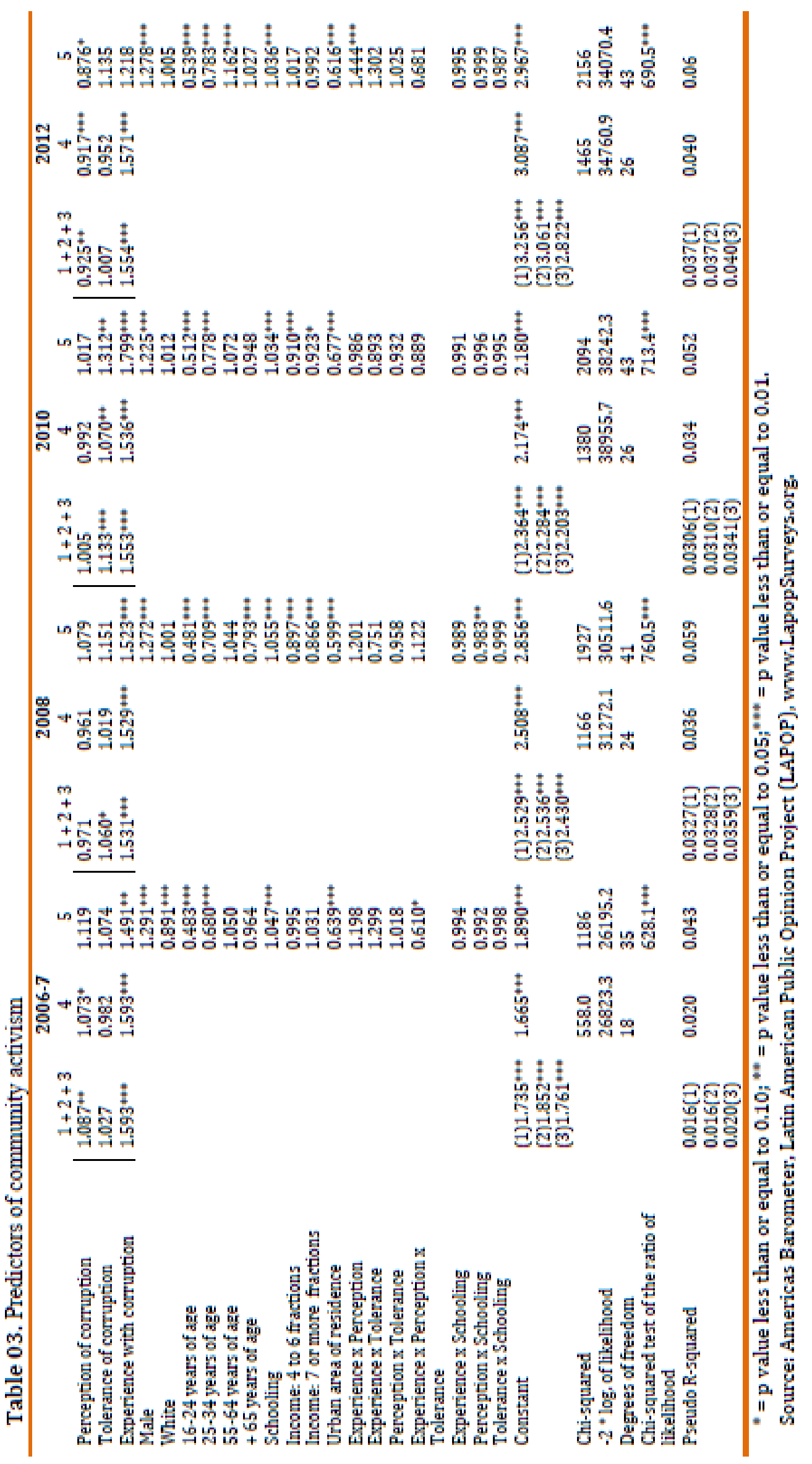


Graph 01. Prediction of general participation according to interactions of indicators of corruption, considering schooling (2012)

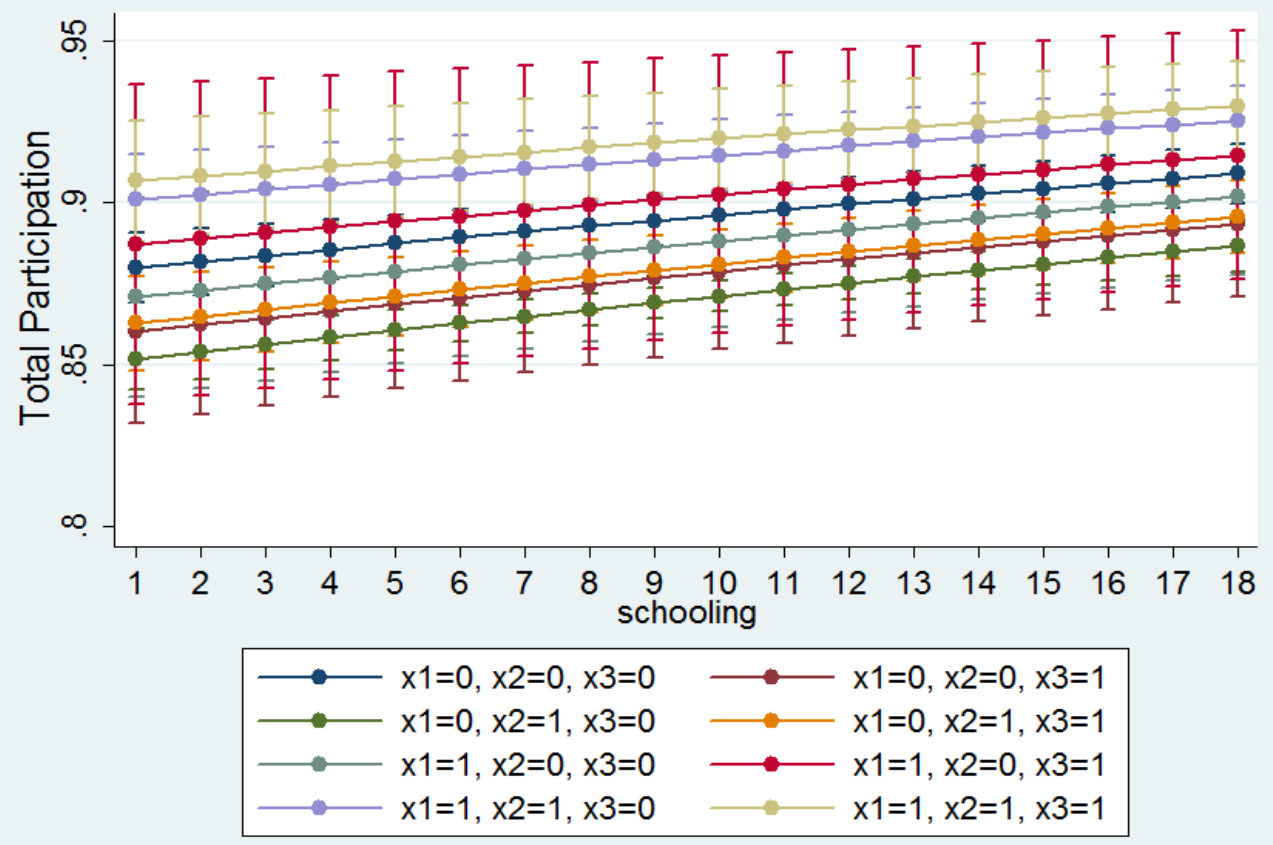

Source: Americas Barometer, Latin American Public Opinion Project (LAPOP).

Note: $\mathrm{x} 1=1$, experience with corruption and $\mathrm{x} 1=0$, no experience with corruption/ $\mathrm{x} 2=1$, perception of corruption and $\mathrm{x} 2=0$, no perception of corruption/ $\mathrm{x} 3=1$, tolerance for corruption and $\mathrm{x} 3=0$, no tolerance for corruption. The graph contains Confidence Intervals.

Graph 02. Prediction of community activism according to indicators of corruption, considering schooling (2012)


Source: Americas Barometer, Latin American Public Opinion Project (LAPOP). 


\section{Final considerations}

The present study provides new insights about the relationship between corruption and political participation in the Americas and the Caribbean. It extends the time period and the number of cases than previous studies as well as it brings new aspects to the study of this subject. Its results reinforce the necessity, advanced by specialized literature, to understand the phenomenon as plural and no longer as singular. That is, we believe that it is more appropriate that we speak of "political participations" rather than "political participation". Moreover, it shows the necessity to analyze voter turnout aside from other modalities of participation, since the results of its associations with the explanatory variables were shown to be highly discordant.

Booth and Seligon's (2009) study might be the first one that dealt, in a more comprehensive way, with the dimensionality of political participation in the Americas and the Caribbean, using restricted data from the 2004 round of the AB. The modalities of political participation they found are similar to those identified by us, although there are some differences in the statistical techniques used and the time period analyzed. We understand that the similarities in the results enable us to state that the logic of political participation, in the context analyzed, revolves around five sets of activities, as follows: (01) contact with political and governmental actors, (02) community activism, (03) electoral and partisan activism, (04) voter turnout and (05) protest activism.

Additionally, this study revealed that that the frequency of experience with corruption and the perception of corruption are shown to be stable from 2004 on, although with very different magnitudes. However, tolerance for corruption, which expresses a value, has diminished throughout the same period. However, the available data do not allow us to investigate whether this is a result of a change in values or just a consequence of a socially desirable position of the respondent during the conduct of the research.

Regarding the possible relationship between corruption and political participation, our results allow to advance that tolerance for and experience with corruption increase the likelihood of participation, contrary to what previous studies have found. Nevertheless, the intensity of the associations is stronger and the presence of statistical significance is more numerous in the case of experience 
with corruption. As for the perception of corruption, the results appear highly varied, making it difficult to identify any trend.

The results relative to experience with corruption give us a glimpse of the existence of a relationship and not of a mere association with the modalities of participation, with the exception of those relative to voter turnout. The same could be stated regarding schooling, with the difference that it applies to any modality. Our results indicate that the experience with situations of bribes have a central role in the political engagement of Americans and Caribbeans. Such indications enable us to suggest that experience with corruption is the most appropriate indicator of the phenomenon for discriminating participative behavior.

However, we are aware of some limitations of the present study. We believe that the analysis may be refined in future studies by the inclusion, for example, of more contextual variables in the statistical tests performed. It would also be interesting to analyze particular cases within the universe of the Americas and the Caribbean, to verify whether the principle findings of the present study are supported. Finally, we think that studies which follow this research problem should go one step further: we verified that the greater the experience with and tolerance for corruption, the greater the likelihood of political engagement; but, what are the mechanisms involved in this relationship? Are politically active individuals who experience corruption closely more or less permissive of acts of corruption? In other words, are those individuals willing to change the political system so that it becomes fairer or in ways that would help them seek material gains from their insertion in corrupt networks? In summary, the present study is innovative and reaches important conclusions, but it also opens the space for a vast field of research.

Translated by Viamundi Submitted in September 2014

Accepted in February 2015

\section{References}

ABRAMO, Cláudio (2004), Still Lifes: Perceptions of Corruption vs Other Indicators. Notes to the seminar: Entendiendo la Corrupción en el Continente Americano, Laboratorio de Análisis y Documentación de la Corrupción. Instituto de Investigaciones Sociales. Universidad Nacional Autónoma de México. 
ABRAMO, Cláudio (2005a), How far go perceptions? Working paper. Transparência Brasil.

ABRAMO, Cláudio (2005b), Percepções pantanosas: a dificuldade de medir a corrupção. Novos Estudos Cebrap. Vol. 73.

BOHN, Simone (2012), Corruption in Latin America: understanding the perceptionexposure gap. Journal of Politics in Latin America. Vol. 04, № 03. pp. 67-95.

BONIFÁCIO, Robert (2014), Corrupção e participação política nas Américas e no Caribe: 2004-2012. PhD Dissertation. Faculdade de Filosofia e Ciências Humanas. Universidade Federal de Minas Gerais.

BOOTH, John and SELIGSON, Mitchell (2009), The legitimacy puzzle in Latin America: political support and democracy in eight nations. Cambridge: Cambridge University Press. 376p.

BORBA, Julian (2012), Participação política: uma revisão dos modelos de classificação. Sociedade e Estado. Vol. 27, № 02. pp. 263-288.

BRADY, Henry (1999), Political participation. In: Measures of political attitudes. Edited by ROBINSON, John. San Diego: Academic Press. pp. 737-800.

CALERA, Nicolás (1997), Corrupción, ética y democracia: nueve tesis sobre la corrupción política. In: La corrupción política. Edited by IBÁÑEZ, Perfecto; LAPORTA, Francisco and ALVAREZ, Silvina. Madrid: Alianza Editorial. pp. 117134.

DELLA PORTA, Donatella (2000), Social capital, beliefs in government and political corruption. In: Disaffected democracies: what's troubling the trilateral countries? Edited by PHARR, Susan. Princeton: Princeton University Press. pp. 202-228.

DOIG, Alan and McIVOR, Stephanie (1999), Corruption and its control in the developmental context: an analysis and selective review of the literature. Third World Quarterly. Vol. 20, № 03. pp. 657-676

DOIG, Alan and THEOBALD, Robin (2000), Corruption and democratisation. Londres: Frank Cass. 176p.

EUBEN, J.P. (1989), Corruption. In: Political Innovation and conceptual change. BALL, Terence; FARR, James and HANSON, Russell (Ed). Cambridge: Cambridge University Press. pp. 220-246.

FIALHO, Fabrício (2008), Participação e desigualdade política: um exercício em teoria e método. Master Dissertation. DCP/UFMG, Belo Horizonte. 
FILGUEIRAS, Fernando (2008), Marcos teóricos da corrupção. In: Corrupção: ensaios e críticas. Edited by AVRITZER, Leonardo et al. Belo Horizonte: Editora UFMG. pp. 299-306.

HEIDENHEIMER, Arnold; JOHNSTON, Michael and LEVINE, Victor (1989), Introduction to part I. In: Political corruption: a handbook. Edited by HEIDENHEIMER, Arnold; JOHNSTON, Michael and LEVINE, Victor. New Brunswich: Transaction Publishers.

HIRSCHMAN, Albert (1983), De consumidor a cidadão: atividades privadas e participação na vida pública. São Paulo: Brasiliense. 145p.

HUNTINGTON, Samuel (1968), Political order in changing societies. New Haven: Yale University Press. 488p.

HUNTINGTON, Samuel (1994), A terceira onda: a democratização no final do século XX. São Paulo: Ática. 335.p

LEE, Valerie (2008), Utilização de modelos hierárquicos lineares para estudar contextos sociais. In: Pesquisa em eficácia escolar: origem e trajetórias. Edited by BROOKE, Nigel and SOARES, Francisco. Belo Horizonte: UFMG. pp. 273-298.

LIPSET, Seymour and LENZ, Gabriel (2002), Corrupção, cultura e mercados. In: $A$ cultura importa. Edited by HARRISON, Lawrence and HUNTINGTON, Samuel. Rio de Janeiro: Record. pp. 173-190.

LONG, Scott and FREESE, Jeremy (2006), Regression Models for Categorical Dependent Variables Using Stata. Texas: Stata Press. 527p.

MANZETTI, Luigi and WILSON, Carole (2009), Why do corrupt governments maintain public support? In: Corruption and democracy in Latin America. Edited by BLAKE, Charles and MORRIS, Stephen. Pittsburgh: University of Pittsburgh Press. pp. 86-102.

MILBRAITH, Lester (1965), Political participation: how and why do people get involved in politics? Chicago: Rand McNally and Company. 195p.

MOISÉS, José Álvaro (1992), Democratização e cultura política de massas no Brasil. Lua Nova, № 26. pp. 05-51.

NORRIS, Pippa (2002), Democratic Phoenix: reinventing political activism. Cambridge: Cambridge University Press. 290p.

NORRIS, Pippa (2011), Democratic deficit: critical citizens revisited. Cambridge: Cambridge University Press. 335p.

NYE, Joseph (1967), Corruption and political development: a cost-benefit analysis. The American Political Science Review. Vol. 61, № 02. pp. 417-427. 
PASQUINO, Gianfranco (1990), Curso de Ciência Política. Lisboa: Princípia. 496p.

PIZZORNO, Alessandro (1975), Introducción al estudio de la participación política. In: Participación y cambio social em la problemática contemporánea. Edited by PIZZORNO, Alessandro; KAPLAN, Marcos and CASTELLS, Manuel. Buenos Aires: Siap-Planteos. pp. 13-82.

REIS, Fábio (2000), Mercado e utopia: teoria política e sociedade brasileira. São Paulo: Edusp. 416p.

ROSE-ACKERMAN, Susan (1999), Corruption and government: causes, consequences and reform. Cambridge: Cambridge University Press. 266p.

SALINAS, Eduardo and BOOTH, John (2011), Micro social and contextual sources of democratic attitudes in Latin America. Journal of Politics in Latin American. Vol. 03, № 01. pp. 29-64.

SELIGSON, Mitchell (2001), Corruption and democratization: what is to be done? Public integrity. Vol. 03, № 03. pp. 221-241.

SELIGSON, Mitchell (2002), The impact of corruption on regime legitimacy: a comparative study of four Latin American countries. Journal of politics. Vol. 64, № 02.pp. 408-433.

SEÑA, Jorge (1989), El fenómeno de la corrupción. In: La corrupción política. Edited by IBÁÑEZ, Perfecto; LAPORTA, Francisco and ALVAREZ, Silvina. Madrid: Alianza Editorial. pp. 71-90.

TEORELL, Jan; TORCAL, Mariano and MONTERO, José Ramon (2007), Political participation: mapping the terrain. In: Citizenship and involvement in European democracies. Edited by DETH, Jan Van; MONTERO, José Ramon and WESTHOLM, Anders. New York: Routledge. pp. 334-357.

VALDÉS, Ernesto (1995), Acerca del concepto de corrupción. Claves de razón práctica. № 56. pp. 26-39.

VERBA, Sidney; NIE, Norman and KIM, Jae-on (1987), Participation and political equality: a seven-nation comparison. New York: University of Chicago Press. 394p.

WARREN, Mark (2012), The Meaning of Corruption in Democracies. In: The Routledge International Handbook on Political Corruption. Edited by HEYWOOD, Paul. Oxford: Routledge. pp. 42-55.

ZÉPHYR, Dominique (2008), Corruption and its impact on Latin American democratic stability. Challenges to Democracies in Latin American and the Caribean. Evidence from the Americas Barometer 2006-2007. Vanderbilt University/ United States Agency for International Development. 